\title{
Comparative Cytogenetic and PCR Studies in Fragile $X$ Syndrome
}

\author{
Greicy H. R. Gambarini ${ }^{1}$, Valter A. Della-Rosa ${ }^{1, *}$ \\ and Ana Maria S. Machado de Moraes ${ }^{2}$ \\ ${ }^{1}$ Departamento de Biologia Celular e Genética, Universidade Estadual de Maringá, 87020-900, Maringá, \\ Paraná, Brazil \\ ${ }^{2}$ Departamento de Medicina, Universidade Estadual de Maringá, 87020-900, Maringá, Paraná, Brazil
}

Received April 20, 2005; accepted May 17, 2005

\begin{abstract}
Summary Fragile X syndrome has been recognized as the second most common cause of mental retardation after Down's syndrome, and has been diagnosed by cytogenetic and molecular analyses. Results from cytogenetic and molecular studies by Polymerase Chain Reaction (PCR) techniques in 34 patients suspected of fragile X syndrome (FRAXA) are compared. Results were similar: in five patients with karyotype 46,Yfra(X)(q27.3) the PCR technique also revealed mutation of FMR1 gene. In the other 29 patients who failed to express fragile X chromosome, PCR technique also showed the absence of mutation of FMR1 gene. Although PCR technique guaranteed fast FRAXA search, the cytogenetic study was as efficient as the PCR technique to diagnose fragile chromosome X syndrome in mentally retarded subjects.
\end{abstract}

Key words Fragile X syndrome, FRAXA, FMR1 gene, Karyotype, PCR, Mental retardation.

Fragile $\mathrm{X}$ syndrome has been recognized as the second most common cause of mental retardation (MR) after Down's syndrome (Brown et al. 1985), and affects almost 4.4/10,000 males and 4.1/10,000 females (Sherman et al. 1984). It is an X-linked inheritance syndrome, characterized by MR, macroorchidism and mild facial anomalies, including elongated face with large and protruding ears (Hagerman 1996). Diagnosis of FRAXA patients is made by cytogenetic analysis for fragile sites and/or molecular studies. Fragile X chromosome (FRAXA) (OMIM 309550), identified by chromosome analysis, is related to a cytogenetic marker, or rather, the folate-sensitive fragile site, in which chromatin fails to condense during mitosis. It is thus typified by a constriction and break trends close to the interface between the last two bands at Xq27.3 (Fig. 1A). Cytogenetic condition is caused by disorder in sequence CGG replication in non-translated region 5' of gene FMR1 (fragile X mental retardation) (Slaney et al. 1995). Whereas trinucleotides in normal persons repeat themselves between 6 and 50 times, in syndrome-conditioned ones with full mutation they replicate themselves more than 200 times, coupled to hypermethylation in the same region (Pieretti et al. 1991). Normal people, premutation carriers, have 55-200 repetition copies (Brown et al. 1993, Fu et al. 1991).

Molecular study detects gene mutations by amplification of DNA fragments by Polymerase Chain Reaction (PCR) (Fu et al. 1991, Heitz et al. 1992, Haddad et al. 1996, Pena and Sturzeneker 1999) and quickly identifies carriers of gene FMR1 full mutation. Haddad et al. (1996) described a protocol in which FRAXA males, carriers of gene FMR1 full mutation, are identified by lack of amplification of mutated alleles. On the other hand, since normal or premutation allele is always amplified, distinction between normal individuals and premutation carriers fails. Due to the preferential amplification of the normal allele, the above methodology also fails in identifying females

\footnotetext{
* Corresponding author, e-mail: vadrosa@uem.br
} 
who are premutation or full mutation carriers.

Results from cytogenetic and PCR studies in patients suspected of fragile $\mathrm{X}$ syndrome (FRAXA) are compared.

Materials and methods

\section{Selection of patients}

Thirty-four MR male patients, with suspected of fragile X syndrome, were selected from population attended at the Genetic Counseling and Human Cytogenetic Unit of the State University of Maringá PR Brazil. Experiment was approved by the Permanent Ethics Committee in Research on Humans of UEM and by the Brazilian Ethics Commission in Research (CONEP/CNS/MS).

\section{Cytogenetic study}

Samples of peripheral venous blood of each patient, collected with sodium heparin, were submitted to temporary lymphocyte cultures $(72 \mathrm{~h})$, according to Moorhead et al. (1960), modified. Two cultures were prepared for each patient, with culture medium RPMI1640 without folic acid (GIBCO-BRL of Brazil), supplemented by bovine fetal serum (GIBCO-BRL of Brazil) 15\%, phytohemagglutinin (GIBCO-BRL of Brazil) 4\%, plus FudR (5-fluordesoxyuridine-Sigma) at $5 \times 10^{-6} \mathrm{M}$ or Trimetroprim (Sigma) at $26 \mu \mathrm{g} / \mathrm{ml}, 24 \mathrm{~h}$ before collection.

Modified Seabright (1971) GTG band technique was employed to identify, besides fragile sites, possible karyotype changes.

\section{Molecular study}

Samples of peripheral venous blood were collected from each patient and submitted to genome DNA extraction, according to methodology by Pena et al. (1991). PCR technique (Haddad et al. 1996) was then employed with primers Eag-U (5'-cgacctgtcaccgccettcagccttcc $3^{\prime}$-sense) and Eag-L (5'-cgctgcgggtgtaaacactgaaaccacgtc $3^{\prime}$-anti-sense) (Haddad et al. 1996) and $\mathrm{f}$ (5'-agcccegacacttccaccaccagctcctcca $3^{\prime}$-anti-sense) (Fu et al. 1991), produced by GIBCO-BRL of Brazil. Three tubes were provided for assay control: first, without any genomic DNA, for contamination of reactions; second, with DNA sample of a full mutation gene FMRI carrier, karyotype 46, Y fra(X)(q27.3) and confirmed by Southern blotting with probe StB12.3, after double ingestion with EcoRI and EagI; third, with DNA sample of a normal male adult. Products of PCR reaction were separated by electrophoresis in non-denaturing polyacrylamide $6 \%$ and visualized by silver staining (Santos et al. 1993).

\section{Results}

The cytogenetics studies for fragile $\mathrm{X}$ chromosome was performed in 34 patients. Normal karyotype (46, XY) was found in 26 patients, while 3 patients had abnormal karyotypes: 46,XY,ins(2)(pter $\rightarrow$ p22::p11.1 $\rightarrow$ q33::p21 $\rightarrow$ p11.2::q34 $\rightarrow$ qter); 46,XY,22p+; 47,XY,+mar, respectively.

In the others 5 the diagnosis, based in cytogenetic studies for Fragile $\mathrm{X}$ chromosome syndrome was established. They have revealed karyotype 46, $\mathrm{Yfra}(\mathrm{X})(\mathrm{q} 27.3)$. Twenty-one to 152 metaphase cells from all 34 patients were analyzed in search of fragile sites, with average 58.1 cells/patient. The diagnosis is established in patients that exhibit metaphases, with chromosome $\mathrm{X}$ that have the fragile site in Xq27.3 region (Fig. 1A). This value was ranging from 6 to $24 \%$ in the cells analyzed because in the same patient, with diagnosis of FRAXA, the majority of the others metaphases exhibit the X chromosome without the fragile site in Xq27.3 region (Fig. 1B).

A currently employed molecular study detects gene mutations by amplification of DNA frag- 
ments by PCR was performed too in the same 34 patients, to compare with cytogenetic results. In the Fig. 2 we can see the results from PCR reaction in 4 patients with mental retardation (lanes 1 to 4 ) and an affected patient for FRAXA (lane 6). A 557 bp polymorphic band, amplified by primers Eag-U and f, identifies patients without FRAXA (Fig. 2-lanes 1, 2, 3, 4) and normal male control (Fig. 2-lane 7). The lane 5 (Fig. 2) is a tube with reaction control without DNA and the lane 8 is the molecular weight marker $100 \mathrm{bp}$ DNA. In the lane 6 (Fig. 2) we can see the lack of band that identifies the full mutation FMR1 gene carrier owing to an in tandem expansion of CGG trinucleotides for more than 200 times in the individual's gene. A $223 \mathrm{bp}$ monomorphic band, amplified by primers Eag-U and Eag-L, turns up to be an internal control of PCR reaction and its amplification reveals PCR reaction in FMR1 gene.

Mutation of FMR1 gene, gauged by PCR technique, showed the absence of amplification of $557 \mathrm{bp}$ allele in 5 out 34 patients, the same that showed the karyotype 46,Yfra(X)(q27.3). These were gene FMR1 mutation carriers. Amplification of $557 \mathrm{bp}$ allele occurred in the other 29 patients who failed to express fragile $\mathrm{X}$ chromosome. This fact revealed that these patients were not mutation carriers.

\section{Discussion and conclusion}

Data coincided when results of cytogenetWhereas karyotypes 46 , Y fra $(\mathrm{X})(\mathrm{q} 27.3)$ were found in 5 patients, $\mathrm{PCR}$ investigation coincidentally revealed gene FMR1 mutation. Cytogenetic study in the other patients revealed lack of fragile site at Xq27.3, while PCR investigation showed absence of gene FMR1 mutation.

Data above are not exactly similar to those found in the literature. When cytogenetic studies were compared to molecular ones, several authors have found rare males with full mutation of gene FMR1 without its cytological manifestation (Hirst et al. 1991, Nakahori et al. 1991, Tarlenton et al. 1992, Knobloch et al. 1993, Ramos et al. 1993). We agree with Mingronni-Netto (1994) when she accounted these authors for methodological problems when no concordance between cytogenetic and molecular studies existed in these rare cases.

Although fastness, relatively low costs, non-use of radioactive material and the need of only small quantities of DNA are assets in PCR technique, the method has its disadvantages. First, since normal allele (CGG)n should be preferentially amplified and not mutated, it cannot be used to detect heterozygous females. Second, male patients with mosaicism may have false negative results, such as occurs with heterozygous females. Third, technique fails to identify non-common point mu- 
tations, found in mentally retarded and autistic Japanese patients (Shinahara et al. 2004). Besides, examination of MR male carriers may not be restricted to PCR technique since it only identifies a single mutation type of a single gene, or rather, FRAXA. Since inherited MR, linked to chromosome X, may be caused by other fragile sites, such as FRAXE (OMIM 309548) and FRAXF (OMIM 300031), the cytogenetic analysis for fragile sites should also be undertaken in suspected cases of fragile $\mathrm{X}$ syndrome.

The search for karyotype changes is always indicated for an MR patient with or without apparent dysmorphic signs. Such requirements were mandatory in our assay since 3 out 34 patients (almost $10 \%$ of sample) with no apparent FRAXA, had other karyotype changes: 46,XY,ins(2)(pter $\rightarrow$ p22::p11.1 $\rightarrow$ q33::p21 $\rightarrow$ p11.2::q34 $\rightarrow$ qter); 46,XY,22p $+; 47, X Y,+$ mar-that justified MR attributes.

One can safely say that molecular study by PCR is indicated for quick selections in male patients when search for gene FMR1's mutation is required. Cytogenetic studies from cell culture in medium without folic acid should also be employed since they are an excellent diagnosis method for fragile sites of MR-linked chromosome X. Coupled to cytogenetic studies for fragile sites, PCR technique may diagnose fragile $\mathrm{X}$ syndrome with greater precision.

\section{Acknowledgements}

Thanks are due to Dr. Angela M. Vianna-Morgante of the Laboratory of Human Genetics of IB-USP for Southern Blot exam of control patient, carrier of fragile X syndrome.

\section{References}

Brown, W. T., Gross, A. C., Chan, C. B. and Jenkins, E. C. 1985. Genetic linkage heterogeneity in the fragile X syndrome. Hum. Genet. 71: 11-18.

—, Houck, G. E., Jeziorowska, A., Levinson, F. N., Ding, X., Dobkin, C., Zhong, N., Henderson, J., Brooks, S. S. and Jenkins, E. C. 1993. Rapid fragile X carrier screening and prenatal diagnosis using a non-radioactive PCR test. JAMA 270: $1569-1575$.

Fu, Y. H., Kuhl, D. P. A., Pizzuti, A., Pieretti, M., Sutcliffe, J. S., Richards, S., Verkerk, A. J. M. H., Holden, J. J. A., Fenwick, R. G. Jr., Warren, S. T., Oostra, B. A., Nelson, D. L. and Caskey, C. T. 1991. Variation of the CGG repeat at the fragile X site results in genetic instability: resolution of the Sherman paradox. Cell 67: 1047-1058.

Haddad, L. A., Mingroni-Neto, R. C., Vianna-Morgante, A. M. and Pena, S. D. 1996. A PCR-based test suitable for screening for fragile-X syndrome among mentally retarded males. Hum. Genet. 97: 808-812.

Hagerman, R. J. 1996. Physical and behavioral phenotype. In: Hagerman, R. J. and Silverman, A. C. (eds.). Fragile X Syndrome: Diagnosis, Treatment and Research. The John Hopkins University Press, Baltimore and London. pp. 3-87.

Heitz, D., Devys, D., Imbert, G., Kretz, C. and Mandel, J.-L. 1992. Inheritance of the fragile X syndrome: size of the fragile $\mathrm{X}$ pre-mutation is a major determinant of the transition to full mutation. J. Med. Genet. 29: 794-801.

Hirst, M. C., Nakahori, Y., Knight, S. J. L., Schwartz, C., Thibodeau, S. N., Roche, A., Flint, T. J., Connor, J. M., Fryns, J. P. and Davies, K. E. 1991. Genotype prediction in fragile X syndrome. J. Med. Genet. 28: 824-829.

Knobloch, O., Pelz, F., Wick, U., Nelson, D. L. and Zoll, B. 1993. Direct versus indirect molecular diagnosis of fragile X mental retardation in 40 German families at risk. J. Med. Genet. 30: 193-197.

Mingronni-Netto, R. C. 1994. Syndrome do cromossomo X frágil: estudo molecular e citogenético. Doctoral Thesis in Biology/Genetics. Instituto de Biociências da Universidade de São Paulo. p. 73.

Moorhead, P. S., Nowell, P. C., Mellman, W. J., Battips, D. M. and Hungerford, D. A. 1960. Chromosome preparations of leukocytes cultured from human peripheral blood. Exp. Cell Res. 20: 613-616.

Nakahori, Y., Knight, S. J. L., Holland, J., Schwartz, C., Roche, A., Tarleton, J., Wong, S., Flint, T. J., Froster-Iskenius, U., Bentley, D., Davies, K. E. and Hirst, M. C. 1991. Molecular heterogeneity of the fragile X syndrome. Nucleic Acids Res. 19: 4355-4359.

OMIM 2004. Online Mendelian Inheritance in Man, OMIM TM http://www.ncbi.nlm.nih.gov/Omim/ Center for Medical Genetics, Johns Hopkins University and National Center for Biotechnology Information, National Library of Medicine.

Pena, S. D. J. and Sturzeneker, R. 1999. Diagnosis of the fragile X syndrome in males using methylation-specific PCR of the FMR1 locus. Genetics and Molecular Biology 22: 169-172.

—, Macedo, A. M., Gontijo, N. F., Medeiros, A. M. and Ribeiro, J. C. C. 1991. DNA bioprints: simple non-isotopic DNA 
fingerprints with biotinylated probes. Electrophoresis 12: 146-152.

Pieretti, M., Zhang, F. P., Fu, Y. H., Warren, S. T., Oostra, B. A., Caskey, C. T. and Nelson, D. L. 1991. Absence of expression of the FMR-1 gene in fragile X syndrome. Cell 66: 817-822.

Ramos, F. J., Eunpu, D. L., Finucane, B. and Pfender, E. G. 1993. Direct DNA testing for fragile X syndrome. Am. J. Dis. Child. 147: 1231-1235.

Santos, F. R., Pena, S. D. J. and Epplen, J. T. 1993. Genetic and population study of an Y-linked tetranucleotide repeat DNA polymorphism with a simple non-isotopic technique. Hum. Genet. 90: 655-656.

Seabrigt, M. 1971. A rapid banding technique for human chromosomes. Lancet II. 971-972.

Sherman, S. L., Morton, N. E., Jacobs, P. A. and Turner, G. 1984. The marker (X) syndrome: a cytogenetic and genetic analysis. Ann. Hum. Genet. 48: 21-37.

Shinahara, K., Saijo, T., Mori, K. and Kuroda, Y. 2004. Single-strand conformation polymorphism analysis of the FMR1 gene in autistic and mentally retarded children in Japan. J. Med. Invest. 51: 52-58.

Slaney, S. F., Wilkie, A. O. M., Hirst, M. C., Charton, R., McKinley, M., Pointon, J., Christodoulou, Z., Huson, S. M. and Davies, K. E. 1995. DNA testing for fragile X syndrome in schools for learning difficulties. Archives of Disease in Childhood 72: 33-37.

Tarleton, J., Wong, S. and Schwartz, C. 1992. Direct analysis of the FMR1 gene provides an explanation for an exceptional case of a fragile X negative, mentally retarded male in a fragile X family. J. Med. Genet. 29: 919-920. 